\title{
MACIEJ ETEL
}

ORCID: 0000-0003-1740-4688

Uniwersytet w Białymstoku

etel.m@uwb.edu.pl

\section{Prawo przedsiębiorców nowa jakość i stare problemy}

\begin{abstract}
Abstrakt: Ustawa z dnia 6 marca 2018 roku Prawo przedsiębiorców, która weszła w życie 30 kwietnia 2018 roku, kontynuuje ugruntowaną w prawie polskim tradycję regulowania zasad podejmowania, wykonywania i zakończenia działalności gospodarczej ustawą o konstytucyjnym umocowaniu, nadrzędnym charakterze, zadaniach i treści. Niniejsze opracowanie ukazuje potrzebę reform, istotę, konstrukcję i zakres regulacji, a także nowe instytucje prawne kształtujące gwarancje wolności gospodarczej i kreujące wzorzec pożądanej relacji organów władzy publicznej z przedsiębiorcą. Na tej podstawie formułuje ocenę reformy oraz postulaty de lege lata i de lege ferenda.
\end{abstract}

Słowa kluczowe: prawo przedsiębiorców, działalność gospodarcza, reforma, nowa podstawa prawna, tradycyjne problemy.

\section{Wprowadzenie}

Ustawa z dnia 6 marca 2018 roku Prawo przedsiębiorców ${ }^{1}$ weszła w życie 30 kwietnia $2018 \mathrm{roku}^{2}$. Akt ten wstąpił w rolę i funkcje ustawy z dnia 2 lipca 2004 roku o swobodzie działalności gospodarczej ${ }^{3}$, co oznacza, że kontynuuje ugruntowaną już $\mathrm{w}$ prawie polskim tradycję regulowania zasad podejmowania,

${ }^{1}$ Ustawa z dnia 6 marca 2018 roku Prawo przedsiębiorców (tekst jedn. Dz.U. z 2019 r. poz. 1292 ze zm.); dalej: u.PP.

2 Art. 1 ust. 1 ustawy z dnia 6 marca 2018 roku Przepisy wprowadzające ustawę — Prawo przedsiębiorców oraz inne ustawy dotyczące działalności gospodarczej (Dz.U. z 2018 r. poz. 650); dalej: przepisy wprowadzające.

${ }^{3}$ Ustawa z dnia 2 lipca 2004 roku o swobodzie działalności gospodarczej (tekst jedn. Dz.U. z 2017 r. poz. 2168 ze zm.); dalej: u.SDG. 
wykonywania i zakończenia działalności gospodarczej ustawą o konstytucyjnym umocowaniu, nadrzędnym charakterze, zadaniach i treści ${ }^{4}$.

Celem niniejszego opracowania jest ukazanie potrzeby, celów i priorytetów reform, przedstawienie istoty, konstrukcji oraz zakresu regulacji, a także wskazanie nowych instytucji prawnych w przekonaniu legislatora kształtujących gwarancje wolności gospodarczej i kreujących wzorzec relacji organów władzy publicznej z przedsiębiorcą.

$\mathrm{Na}$ tej podstawie zostanie dokonana wstępna ocena nowej regulacji oraz wprowadzonych zmian. Ponadto zostaną sformułowane postulaty de lege lata i de lege ferenda, a także odpowiedź na pytania: czy i ewentualnie w jakim zakresie zrealizowane reformy odpowiadają rzeczywistym potrzebom, czy wytyczają nowe standardy i czy mają szansę realnie przyczynić się do poprawy sytuacji prawnej przedsiębiorcy.

\section{Priorytety i cele reform}

Zgodnie z uzasadnieniem ustawy Prawo przedsiębiorców ${ }^{5}$ priorytetowym założeniem reform jest osiągnięcie dalekosiężnych celów, takich jak tworzenie warunków trwałego wzrostu gospodarczego, wzrostu dochodów mieszkańców oraz spójności w wymiarze społecznym, ekonomicznym i terytorialnym kraju6 .

Podjęte działania legislacyjne są natomiast środkiem realizacji, który ma zachęcić przedsiębiorców do rozwijania działalności gospodarczej i dokonywania nakładów inwestycyjnych, co w rezultacie ma powodować pozytywne skutki gospodarcze ${ }^{7}$. Zasadniczym celem zmian jest bowiem urzeczywistnienie konstytucyjnej zasady wolności działalności gospodarczej, zapewnienie szerszej swobody w podejmowaniu, wykonywaniu i zakończeniu działalności gospodarczej, stworzenie efektywnych gwarancji i zabezpieczeń niezakłóconego korzystania z tej wolności, ochrona praw przedsiębiorców, a także ograniczenie arbitralnego władztwa organów publicznych ${ }^{8}$.

W przekonaniu ustawodawcy warunkiem osiągnięcia tego celu jest jasne oraz trwałe prawo, które będzie dostosowane do potrzeb obrotu gospodarczego, przyjazne $^{9}$ i gwarantujące bezpieczeństwo przedsiębiorców ${ }^{10}$. Za konieczne uznano

${ }^{4}$ M. Etel, Prawo działalności gospodarczej jako instrument rozwoju przedsiębiorczości, [w:] Prawne instrumenty oddziaływania na gospodarke, red. A. Powałowski, Warszawa 2016, s. 28-36.

${ }^{5}$ Uzasadnienie rządowego projektu ustawy - Prawo przedsiębiorców (druk nr 2051 z 21 listopada 2017 roku), www.orka.sejm.gov.pl (dostęp: 1.09.2019).

6 Ibidem, s. 3-4.

7 Ibidem, s. 7-8.

8 Ibidem, s. 3-6.

9 Ibidem, s. 17.

10 Ibidem, s. 7-8. 
zatem odejście od drobiazgowego regulowania na rzecz unormowań o charakterze ogólnym i podstawowym. Umożliwi to szczegółową regulację, uwzględniającą specyfikę danej materii lub dziedziny, w ustawach odrębnych, przy jednoczesnym zachowaniu prymatu lex generalis i jego naczelnej (determinującej i inspirującej) roli w systemie prawa krajowego. W konsekwencji niezbędny jawi się czytelny i kompaktowy akt, zawierający treści o charakterze uniwersalnym i generalnym, tak jak powinno to mieć miejsce w ustawach ogólnosystemowych i kodyfikacyjnych. Jednocześnie zaś regulowanie szczegółowych zagadnień w osobnych i specjalnie im poświęconych ustawach zwiększy spójność, integralność i kompleksowość tych aktów, bez konieczności rozpraszania regulacji jednej materii pomiędzy lex generalis oraz ustawę lub ustawy odrębne ${ }^{11}$.

Zdaniem legislatora zamierzeń tych nie da się zrealizować bez zastąpienia u.SDG nowym aktem prawnym, lepiej dostosowanym do aktualnych oczekiwań przedsiębiorców oraz poważnych wyzwań stojących przed polską gospodarką ${ }^{12}$; u.SDG przestała bowiem ogrywać rolę aktu systemowego ${ }^{13}$. Z jednej strony stała się aktem przeregulowanym, nadmiernie nasyconym drobiazgowymi przepisami prawnymi o charakterze technicznym i wykonawczym ${ }^{14}$. Z drugiej natomiast brakowało w niej uregulowań wielu instytucji prawnych odczuwanych przez przedsiębiorców jako potrzebne i przydatne ${ }^{15}$. Co więcej, ustawy odrębne, z uwagi na problematykę regulowanej materii i specyfikę danej dziedziny działalności gospodarczej, w wielu przypadkach zawierały regulacje sprzeczne i odbiegające od przepisów u.SDG. Ta niespójność i rozproszenie regulacji były mało czytelne dla przedsiębiorców i utrudniały im ustalanie obowiązujących przepisów, a nawet wywoływało wątpliwości odnośnie do tego, czy lex generalis stanowią przepisy u.SDG, czy też przepisy ustawy odrębnej ${ }^{16}$.

Kierując się przedstawionymi motywami, opracowano i uchwalono nowe normatywne fundamenty funkcjonowania przedsiębiorców w Polsce.

\section{Istota reform, model i zakres przedmiotowy regulacji}

Istota reform sprowadza się do:

1. uchwalenia ustawy z dnia 6 marca 2018 roku Prawo przedsiębiorców;

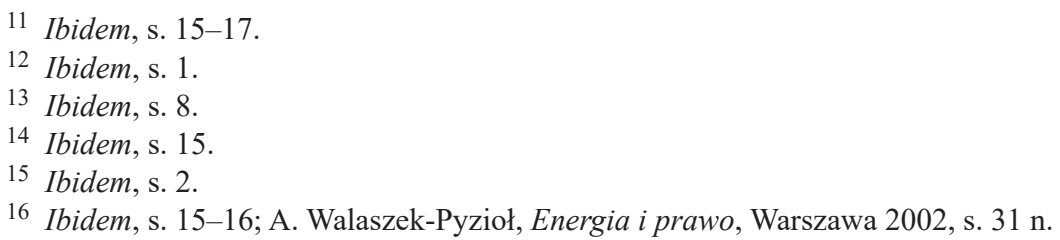


2. uchwalenia aktów współtworzących tak zwaną konstytucję dla biznesu ${ }^{17}$, czyli: (a) ustawy z dnia 6 marca 2018 roku o Centralnej Ewidencji i Informacji o Działalności Gospodarczej i Punkcie Informacji dla Przedsiębiorcy ${ }^{18}$, (b) ustawy z dnia 6 marca 2018 roku o Rzeczniku Małych i Średnich Przedsiębiorców ${ }^{19}$, (c) ustawy z dnia 6 marca 2018 roku o zasadach uczestnictwa przedsiębiorców zagranicznych i innych osób zagranicznych w obrocie gospodarczym na terytorium Rzeczypospolitej Polskiej ${ }^{20}$;

3. uchylenia ustawy z dnia 2 lipca 2004 roku o swobodzie działalności gospodarczej $^{21}$;

4. wprowadzenia zmian w ustawach odrębnych ${ }^{22}$;

5. przyjęcia przepisów przejściowych i dostosowujących ${ }^{23}$.

Symbolem zapowiadanej przez ustawodawcę nowej jakości jest u.PP. Akt ten przejmuje bowiem po u.SDG wypracowane w doktrynie prawa gospodarczego publicznego miano swoistej „konstytucji działalności gospodarczej”, czyli regulacji o szczególnym umocowaniu oraz nadrzędnej roli, funkcjach i treści ${ }^{24}$. Od 30 kwietnia 2018 roku to u.PP u podstaw kształtuje normatywne gwarancje wol-

17 Uzasadnienie rządowego projektu ustawy, s. 1. W myśl art. 1 z zastrzeżeniem art. 1 ust. 1-2 przepisów wprowadzających ustawy wchodzą one w życie 30 kwietnia 2018 roku.

18 Ustawa z dnia 6 marca 2018 roku o Centralnej Ewidencji i Informacji o Działalności Gospodarczej i Punkcie Informacji dla Przedsiębiorcy (tekst jedn. Dz.U. z 2019 r. poz. 1291 ze zm.); dalej: u.CEIDG.

19 Ustawa z dnia 6 marca 2018 roku o Rzeczniku Małych i Średnich Przedsiębiorców (Dz.U. z 2018 r. poz. 648 ze zm.); dalej: u.RMSP.

20 Ustawa z dnia 6 marca 2018 roku o zasadach uczestnictwa przedsiębiorców zagranicznych $\mathrm{i}$ innych osób zagranicznych w obrocie gospodarczym na terytorium Rzeczypospolitej Polskiej (tekst jedn. Dz.U. z 2019 r. poz. 1079 ze zm.); dalej: u.PIOZ.

21 W myśl art. 192 przepisów wprowadzających akt ten utracił moc 30 kwietnia 2018 roku. Ponadto zgodnie z art. 191 i 193 przepisów wprowadzających z dniem 30 kwietnia 2018 roku moc obwiązującą utraciły również ustawa z dnia 6 lipca 1982 roku o zasadach prowadzenia na terytorium Polskiej Rzeczypospolitej Ludowej działalności gospodarczej w zakresie drobnej wytwórczości przez zagraniczne osoby prawne i fizyczne (tekst jedn. Dz.U. z 1989 r. Nr 27, poz. 148 ze zm.) oraz ustawa z dnia 4 marca 2010 roku o świadczeniu usług na terytorium Rzeczypospolitej Polskiej (tekst jedn. Dz.U. z 2016 r., poz. 893 ze zm.; dalej: u.SU).

22 Zob. art. 2-190 przepisów wprowadzających.

23 Zob. art. 194-236 przepisów wprowadzających.

24 O szczególnej roli i treści u.SDG szerzej zob. S. Biernat, A. Wasilewski, Ustawa o działalności gospodarczej. Komentarz, Kraków 1997, s. 13; K. Sobczak, Gospodarka rynkowa a władza publiczna, Warszawa 1998, s. 75; C. Kosikowski, Wolność gospodarcza w prawie polskim, Warszawa 1995, s. 35-36; A. Wasilewski, Zasady prowadzenia działalności gospodarczej w Polsce, „Przegląd Ustawodawstwa Gospodarczego” 1988, nr 5-6, s. 141; A. Walaszek-Pyzioł, Swoboda działalności gospodarczej, Kraków 1994, s. 14-18; C. Kosikowski, Nowe prawo działalności gospodarczej, „Przegląd Ustawodawstwa Gospodarczego” 1999, nr 2, s. 2; Państwo i prawo w gospodarce rynkowej. Problemy dostosowawcze, red. C. Kosikowski, Łódź 1993, s. 13, 69-70; M. Zdyb, Komentarz do ustawy o działalności gospodarczej, Bydgoszcz 1997, s. 9; R. Taradejna, J. Maj, Ustawa o działalności gospodarczej (komentarz), Warszawa 1993, s. 9; S. Biernat, Podejmowanie i prowadzenie działalności gospodarczej - wolność gospodarcza de lege lata $i$ de lege ferenda, 
ności gospodarczej i kreuje wzorzec pożądanej relacji organów władzy publicznej z przedsiębiorcą.

Ustawa składa się z 72 artykułów ujętych w 7 rozdziałach ${ }^{25}$, w których precyzując reguły podejmowania, wykonywania i zakończenia działalności gospodarczej na terytorium Rzeczypospolitej Polskiej (art. 1 u.PP), określa:

1. definicje legalne podstawowych pojęć (art. 7 u.PP), w tym między innymi działalności gospodarczej (art. 3 u.PP) i przedsiębiorcy (art. 4 u.PP);

2. wyłączenia z zakresu stosowania przepisów tego aktu (art. 6 u.PP) oraz z kategorii działalności gospodarczej (art. 5 u.PP); u.PP);

3. zasady relacji organów władzy publicznej z przedsiębiorcą (art. 2 i art. 8-15

4. obowiązki (art. 17-21 i art. 26 u.PP) oraz uprawnienia (art. 22-25 i art. 3435 u.PP) przedsiębiorców;

5. obowiązki organów władzy publicznej wobec działalności gospodarczej (art. 16, art. 33 i art. 36 u.PP);

6. zasady załatwiania spraw z zakresu działalności gospodarczej (art. 27-32 u.PP);

7. cechy relewantne form reglamentacji działalności gospodarczej (art. 37-44 u.PP);

8. zasady kontroli działalności gospodarczej przedsiębiorcy (art. 45-65 u.PP);

9. zasady opracowywania projektów aktów normatywnych z zakresu prawa gospodarczego oraz oceny ich funkcjonowania (art. 66-71 u.PP).

Cechą charakterystyczną reformy jest to, że ustawodawca odstąpił od stosowanego dotychczas modelu normowania ogółu kluczowych kwestii jednym ,nadrzędnym" aktem prawnym ${ }^{26}$. Liczne zagadnienia wyodrębnił bowiem z u.PP na rzecz kompleksowej regulacji w ustawach odrębnych ${ }^{27}$. W ten sposób odniósł się do:

1. Centralnej Ewidencji i Informacji o Działalności Gospodarczej, w szczególności istoty i zadań CEIDG (art. 2-4 u.CEIDG), zasad dokonywania wpisu (art. 5-17 u.CEIDG), wpisu informacji o zawieszeniu i wznowieniu działalności

„Przegląd Prawa Handlowego” 1994, nr 9, s. 11; M. Niezgódka-Medek, M. Szubiakowski, Dziatalność gospodarcza. Spójność systemu prawnego, „Przegląd Prawa Handlowego” 1992, nr 2, s. 6.

25 Są to: rozdział 1. Przepisy ogólne (art. 1-16), rozdział 2. Podejmowanie, wykonywanie i zakończenie działalności gospodarczej (art. 17-26), rozdział 3. Załatwianie spraw z zakresu działalności gospodarczej (art. 27-36), rozdział 4. Reglamentacja działalności gospodarczej (art. 37-44), rozdział 5. Ograniczenia kontroli wykonywania działalności gospodarczej (art. 45-65), rozdział 6. Zasady opracowania projektów aktów normatywnych z zakresu prawa gospodarczego (art. 66-71), rozdział 7. Przepis końcowy (art. 72).

26 Tak jak miało to miejsce w wypadku u.SDG, ustawy z dnia 19 listopada 1999 roku Prawo działalności gospodarczej (Dz.U. Nr 101, poz. 1178 ze zm.), ustawy z dnia 23 grudnia 1988 roku o działalności gospodarczej (Dz.U. Nr 41, poz. 324), a także rozporządzenia Prezydenta Rzeczypospolitej z dnia 7 czerwca 1927 roku o prawie przemysłowem (Dz.U. Nr 53, poz. 468).

$27 \mathrm{Z}$ tego też względu liczba artykułów u.PP (72 artykuły) jest dwukrotnie mniejsza od u.SDG (144 artykuły). 
gospodarczej (art. 18-20 u.CEIDG), informacji dopisywanych z urzędu (art. 2128 u.CEIDG), wykreślenia i sprostowania wpisu (art. 29-37 u.CEIDG), zasady publikowania informacji o pełnomocnikach i prokurentach (art. 38-42 u.CEIDG), udostępniania danych (art. 43-50 u.CEIDG);

2. zadań i zasad funkcjonowania Punktu Informacji dla Przedsiębiorcy (art. 51-66 u.CEDIG);

3. Rzecznika Małych i Średnich przedsiębiorców, w szczególności zadań i uprawnień (art. 1 ust. 1 i art. 8-17 u.RMSP), a także zasad wyboru i odwołania ze stanowiska (art. 2-7 u.RMSP);

4. działalności podmiotów zagranicznych, w tym zasad podejmowania działalności gospodarczej przez osoby zagraniczne na terytorium RP (art. 4 u.PIOZ), form działalności przedsiębiorców zagranicznych w Polsce (art. 2 ust. 2 i art. 1431 u.PIOZ), a także zasad świadczenia usług na terytorium RP oraz współpracy organów międzynarodowych właściwych w tym zakresie (art. 5-13, art. 32-41 oraz art. 42-43 u.PIOZ).

Istotne jest przy tym, że dywersyfikacja treści, co do zasady ujętych dotychczas w u.SDG ${ }^{28}$, pomiędzy cztery ustawy nie spowodowała zwiększenia liczby przepisów $^{29}$. Warto jednak zauważyć, że poszczególne jednostki redakcyjne u.PP są bardziej rozbudowane, niż miało to miejsce w u.SDG.

\section{Nowa jakość regulacji i nowe instytucje prawne}

Wdrożenie nowego modelu regulacji nie powinno zaskakiwać, gdyż jest zgodne z ideą reform - zmierza do uproszczenia prawa, uczynienia go bardziej przejrzystym, przystępnym w odbiorze, a także spójnym, integralnym i wykazującym prymat u.PP jako lex generalis ${ }^{30}$.

Jednocześnie trzeba podkreślić, że nie wyczerpuje to działań ustawodawcy ukierunkowanych właśnie na poprawę technicznej jakości prawa. Świadczy o tym tytuł ustawy, wskazujący wprost na przedsiębiorców, co stanowi odstępstwo od stosowanego dotychczas w prawie polskim przedmiotowego tytułowania tego rodzaju ustaw, to jest przez wskazanie na działalność gospodarczą jako przedmiot danej regulacji ${ }^{31}$. Ważniejsze jest jednak wykorzystanie w tytule słowa „prawo”,

${ }^{28} \mathrm{Z}$ zastrzeżeniem u.SU, a także u.RMSP oraz u.CEIDG w części odnoszącej się do Punktu Informacji dla Przedsiębiorcy.

${ }^{29}$ W sumie u.SDG (144 artykuły) wraz z u.SU (57 artykułów) składały się z 201 artykułów; również u.PP (72 artykuły), u.CEIDG (67 artykułów), u.RMSP (18 artykułów), u.PIOZ (44 artykuły) składają się w sumie z 201 artykułów.

${ }^{30}$ Uzasadnienie rządowego projektu ustawy, s. 7-8, 15-17.

31 Ibidem, s. 9-10. 
które wyraźnie i w sposób odpowiadający wytycznym określonym w zasadach techniki prawodawczej ${ }^{32}$ wyraża systemową rolę u.PP.

Interesujące jest także, iż ustawa została wyposażona w preambułę wyrażającą cele, motywy oraz wartości nadrzędne odnośnie do dalszej treści regulacji, a także w ogóle relacji z przedsiębiorcą ${ }^{33}$. W przekonaniu twórców potwierdza ona doniosłość u.PP, a jednocześnie pełni funkcję wytycznej interpretacyjnej nadającej kierunek wykładni i stosowania jej przepisów ${ }^{34}$.

W celu wzmocnienia dyscypliny legislacyjnej w sferze prowadzenia działalności gospodarczej oraz redukcji obciążeń ponoszonych przez adresatów przepisów prawnych w u.PP sformułowano zasady opracowywania projektów aktów normatywnych z zakresu prawa gospodarczego oraz oceny ich funkcjonowania ${ }^{35}$. Natomiast w dążeniu do jednolitego stosowania przepisów organy władzy publicznej zostały związane obowiązkiem wydawania i publikowania objaśnień prawnych uwzględniających orzecznictwo sądów i trybunałów ${ }^{36}$.

Reformy nie ograniczają się wyłącznie do aspektów technicznych. Zmiany widoczne są również $\mathrm{w}$ warstwie merytorycznej - u.PP tworzy nowe, nieznane przed 30 kwietnia 2018 roku instytucje prawne, a także uzupełnia i poprawia rozwiązania już funkcjonujące na gruncie przepisów u.SDG.

Cechą relewantną u.PP, wyróżniającą ten akt na tle poprzednich ustaw tego rodzaju, jest liczba wyartykułowanych obowiązków organów władzy publicznej $\mathrm{w}$ relacji z przedsiębiorcą i działalnością gospodarczą ${ }^{37}$. Przepisów tej treści jest dużo i mają one zróżnicowany charakter, można bowiem wskazać obowiązki ${ }^{38}$ :

1. ogólne i podstawowe, wyrażone w: (a) preambule; (b) przepisach ogólnych — w szczególności będą to zasady: zaufania do przedsiębiorcy (art. 10 ust. 1 u.PP), rozstrzygania wątpliwości na korzyść przedsiębiorcy (art. 10 ust. 2-3 i art. 11 u.PP), zaufania, proporcjonalności, bezstronności i równego traktowania (art. 12 u.PP), odpowiedzialności (art. 13 u.PP), utrwalonej praktyki rozstrzygania (art. 14

32 W myśl $§ 19$ pkt 2 rozporządzenia Prezesa Rady Ministrów z dnia 20 czerwca 2002 roku w sprawie „Zasad techniki prawodawczej” (tekst jedn. Dz.U. z 2016 r., poz. 283 ze zm.) określenie przedmiotu ustawy może być rzeczowe, to jest rozpoczynające się od wyrazów „Kodeks”, „Prawo” albo „Ordynacja”, pisanych wielką literą, w wypadku gdy ustawa wyczerpująco reguluje obszerną dziedzinę spraw. Zgodnie zaś z $§ 9$ tego aktu w ustawie należy posługiwać się określeniami, które zostały użyte w ustawie podstawowej dla danej dziedziny spraw, w szczególności w ustawie określanej jako „kodeks” lub „prawo”.

33 A. Kraszewski, Preambuła, [w:] Prawo przedsiębiorców. Komentarz, red. A. Pietrzak, LEX 2019.

34 Uzasadnienie rządowego projektu ustawy..., s. 11-12.

35 Ibidem, s. 8; zob. też art. 66-71 u.PP.

36 Zob. A. Piszcz, Objaśnienia prawne wedlug ustawy z 6.3.2018 r. - Prawo przedsiębiorców, „Monitor Prawniczy” 2018, nr 13, dodatek specjalny, s. 14-20.

$37 \mathrm{Z}$ oczywistych przyczyn nakazy i zakazy wiążące państwo mają niebagatelne znaczenie dla przedsiębiorców.

38 Należy przy tym zastrzec, że granice między poszczególnymi grupami są tylko umowne, gdyż obowiązki są komplementarne i uzupełniają się wzajemnie. 
u.PP) oraz udzielania informacji (art. 15 u.PP); (c) przepisach z zakresu załatwiania spraw związanych z działalnością gospodarczą (proceduralne) - będą to zwłaszcza zasady: załatwiania spraw przedsiębiorców bez zbędnej zwłoki (art. 27 u.PP), współdziałania (art. 28 u.PP), związania prawem (art. 29 u.PP), słusznego interesu przedsiębiorcy (art. 30 u.PP), potwierdzenia wpływu wniosku (art. 32 u.PP) oraz jednolitego stosowania prawa (art. 33 u.PP);

2. określone $\mathrm{w}$ przepisach dotyczących opracowywania projektów aktów normatywnych z zakresu prawa gospodarczego oraz oceny ich funkcjonowania (art. 66-71 u.PP) ${ }^{39}$;

3. związane z poszczególnymi płaszczyznami relacji z przedsiębiorcą, to jest: (a) w sferze legalizacji działalności gospodarczej ${ }^{40}$, (b) w sferze reglamentacji działalności gospodarczej ${ }^{41}$, (c) w sferze kontroli działalności gospodarczej ${ }^{42}$;

4. wynikające $\mathrm{z}$ konkretnych instytucji prawnych powstałych $\mathrm{w}$ interesie przedsiębiorcy, czyli: (a) prowadzenia Punktu Informacji dla Przedsiębiorcy ${ }^{43}$, (b) funkcjonowania Rzecznika Małych i Średnich Przedsiębiorców ${ }^{44}$, (c) wydawania interpretacji przepisów i objaśnień prawnych ${ }^{45}$, (d) zawieszenia (i wznowienia) działalności gospodarczej ${ }^{46}$.

Ponadto u.PP poza nowym brzmieniem definicji legalnych z art. $3-4^{47}$ wprowadziła także kategorię działalności formalnie niegospodarczej ${ }^{48}$ — w myśl art. 5 ust. 1 u.PP za działalność gospodarczą nie jest uznawana działalność nieewidencjonowana, to jest wykonywana przez osobę fizyczną, której przychód należny ${ }^{49}$ $\mathrm{z}$ tej działalności nie przekracza $\mathrm{W}$ żadnym miesiącu 50\% kwoty minimalnego wynagrodzenia za pracę ${ }^{50} \mathrm{i}$ która w okresie ostatnich 60 miesięcy nie wykonywała działalności gospodarczej ${ }^{51}$.

39 Zob. S. Patyra, Komentarz do art. 66-77, [w:] Prawo przedsiębiorców. Przepisy wprowadzajace do Konstytucji Biznesu. Komentarz, red. G. Kozieł, Warszawa 2019, s. 321-336.

40 Art. 17-18 i art 26 u.PP, a także art. 2-50 u.CEIDG oraz przepisy ustawy z dnia 20 sierpnia 1997 roku o Krajowym Rejestrze Sądowym (tekst jedn. Dz.U. z 2018 r. poz. 986 ze zm.).

${ }^{41}$ Art. 37-44 u.PP, a także przepisy ustaw odrębnych związanych z konkretnymi rodzajami działalności reglamentowanej.

42 Art. 45-65 u.PP.

43 Art. 36 u.PP oraz art 51-66 u.CEIDG.

44 Art. 16 u.PP, a także przepisy u.RMSP.

45 Art. 33-35 u.PP.

46 Art. 22-25 u.PP.

47 M. Etel, Nowy przedsiębiorca w ustawie z 6 marca 2018 r. - Prawo przedsiębiorców, „Acta Scientifica Academiae Ostroviensis” 2018, nr 2, s. 56-70.

48 A. Piszcz, Komentarz do art. 5, [w:] Prawo przedsiębiorców. Przepisy wprowadzajace..., s. $56-65$.

49 Zgodnie z art. 5 ust. 6 u.PP przez przychód należny rozumie się kwoty należne, choćby nie zostały faktycznie otrzymane, po wyłączeniu wartości zwróconych towarów, udzielonych bonifikat i skont.

${ }^{50}$ O którym mowa w ustawie z dnia 10 października 2002 roku o minimalnym wynagrodzeniu za pracę (tekst jedn. Dz.U. z 2017 r. poz. 847 ze zm.).

51 Ponadto na podstawie art. 195 przepisów wprowadzających przepisy o działalności nieewidencjonowanej stosuje się również do działalności wykonywanej przez osoby, które w okresie roku

Prawo 329, 2020

(C) for this edition by CNS 
Ustawa ta stanowi również podstawę tak zwanej ulgi na start. Zgodnie z art. 18 ust. 1 u.PP przedsiębiorca będący osobą fizyczną, który podejmuje działalność gospodarczą po raz pierwszy albo podejmuje ją ponownie po upływie co najmniej 60 miesięcy od dnia jej ostatniego zawieszenia lub zakończenia i nie wykonuje jej na rzecz byłego pracodawcy, na rzecz którego przed dniem rozpoczęcia działalności gospodarczej w bieżącym lub w poprzednim roku kalendarzowym wykonywał w ramach stosunku pracy lub spółdzielczego stosunku pracy czynności wchodzące w zakres wykonywanej działalności gospodarczej, nie podlega obowiązkowym ubezpieczeniom społecznym przez 6 miesięcy od dnia podjęcia działalności gospodarczej $^{52}$.

Z kolej na mocy art. 16 u.PP powołano Rzecznika Małych i Średnich Przedsiębiorców ${ }^{53}$. Organ ten stoi na straży praw przedsiębiorców, w szczególności poszanowania zasady wolności działalności gospodarczej, pogłębiania zaufania przedsiębiorców do władzy publicznej, bezstronności i równego traktowania, zrównoważonego rozwoju oraz zasady uczciwej konkurencji i poszanowania dobrych obyczajów oraz słusznych interesów przedsiębiorców ${ }^{54}$.

Korzystne dla przedsiębiorców są również korekty i uzupełnienia w instytucjach funkcjonujących przed uchwaleniem u.PP, to jest: zawieszeniu działalności gospodarczej ${ }^{55}$, wydawaniu wiążących interpretacji przepisów z zakresu danin publicznych $^{56}$ oraz dokonywaniu wpisów z zakresu danych dostępnych w CEIDG $^{57}$, a także zawężenie katalogu obowiązków ogólnych ${ }^{58}$.

przed dniem wejścia w życie ustawy nie były wpisane do CEIDG lub które zostały wykreślone z CEIDG więcej niż rok przed dniem wejścia w życie ustawy, nawet jeżeli w czasie ostatnich 60 miesięcy przed dniem wejścia w życie ustawy wykonywały działalność gospodarczą.

${ }^{52} \mathrm{~W}$ myśl art. 18 ust. 2 u.PP przedsiębiorca może zrezygnować z uprawnienia, o którym mowa w art. 18 ust. 1, przez dokonanie zgłoszenia do ubezpieczeń społecznych. Natomiast w myśl art. 18 ust. 3 u.PP ,ulgi na start” nie stosuje się do przedsiębiorców spełniających warunki określone w art. 5a ustawy z dnia 20 grudnia 1990 roku o ubezpieczeniu społecznym rolników (tekst jedn. Dz.U. z 2017 r. poz. 2336 ze zm.). Zob. M. Korzeniewski, Komentarz do art. 18, [w:] Prawo przedsiębiorców. Komentarz...

53 Szczegółowo zadania i uprawnienia Rzecznika, a także zasady wyboru i odwołania ze stanowiska określa u.RMiSP. Zob. CEIDG. Rzecznik Małych i Średnich Przedsiębiorców. Przedsiębiorcy zagraniczni w obrocie gospodarczym. Komentarz, red. G. Kozieł, Warszawa 2019, s. 171235; P. Lissoń, Rzecznik Małych i Średnich Przedsiębiorców: ombudsman czy organ administracji rzadowej, ,Ruch Prawniczy, Ekonomiczny i Socjologiczny” 80, 2018, nr 4, s. 55-71.

54 Art. 1 u.RMiSP.

55 Zob. art. 22-25 u.PP.

56 Zob. art. 34-35 u.PP.

57 Zob. art. 2-50 u.CEIDG.

58 Przepisy tego aktu wskazują wyłącznie na obowiązki: (1) legalizacji działalności gospodarczej — art. 17 u.PP, (2) posługiwania się rachunkiem płatniczym — art. 19 u.PP, (3) posługiwania się numerem identyfikacji podatkowej — art. 20 u.PP, (4) odpowiedniego oznaczenia przedsiębiorcy — art. 20 ust. 3 u.PP, (5) odpowiedniego oznaczenia towaru przedsiębiorcy — art. 21 u.PP.

Prawo 329, 2020

(C) for this edition by CNS 


\section{Wnioski}

Mając na uwadze zaprezentowane informacje, można stwierdzić, że reforma wpłynęła pozytywnie na stan prawa regulującego zasady podejmowania, wykonywania i zakończenia działalności gospodarczej. Można również uznać, że ustawodawcy udało się uchwalić u.PP jako akt nowoczesny, kształtujący nowe standardy relacji organów władzy publicznej z przedsiębiorcą i korzystne podstawy prawne działalności gospodarczej, który doprowadzi do poszerzenia zakresu wolności gospodarczej w Polsce. Przemawia za tym przede wszystkim nowy model regulacji oraz nowy tytuł ustawy i preambuła, podkreślające konstytucyjne umocowanie, systemowy charakter oraz nadrzędne zadania i treści u.PP, poprawiona jakość przepisów, a także kolejne proprzedsiębiorcze instytucje prawne i dokonane korekty w instytucjach funkcjonujących już przed 30 kwietnia 2018 roku.

Ocena zmian nie może być jednak jednoznacznie pozytywna. Nowa „konstytucja działalności gospodarczej" nie jest bowiem wolna od braków i niedoskonałości, a niektóre jej przepisy wzbudzają wątpliwości i kontrowersje ${ }^{59}$. Wbrew oczekiwaniom i postulatom wciąż:

— istotne trudności sprawia identyfikacja działalności gospodarczej i przedsiębiorcy ${ }^{60}$

— równolegle funkcjonuje ponad 60 rejestrów warunkujących legalne wykonywanie działalności gospodarczej ${ }^{61}$, w tym 6 rejestrów, w których uzyskanie wpisu lub dokonanie zgłoszenia jest obligatoryjne dla każdego przedsiębiorcy, mimo to rejestry te nie oddają rzeczywistego stanu przedsiębiorczości w Polsce ${ }^{62}$;

— źródłem obowiązków przedsiębiorców pozostają przede wszystkim ustawy odrębne ${ }^{63}$;

— liczne ustawy odrębne uchylają właściwość przepisów u.PP ${ }^{64}$;

— zbyt rozbudowana jest sfera reglamentacji działalności gospodarczej ${ }^{65}$, a konstrukcje poszczególnych form reglamentacji pozostają wadliwe ${ }^{66}$;

59 Zob. Opinia Rady Legislacyjnej przy Prezesie Rady Ministrów z dnia 7 kwietnia 2017 roku o projekcie ustawy - Prawo przedsiębiorców, www.radalegislacyjna.gov.pl (dostęp: 10.06.2018).

60 Zob. M. Etel, Pojęcie przedsiębiorcy w prawie polskim i prawie Unii Europejskiej oraz w orzecznictwie sadowym, Warszawa 2012, s. 171-273 oraz wskazana tam literatura i orzecznictwo.

61 Zob. C. Kosikowski, M. Etel, Nowe prawo działalności gospodarczej, Białystok 2014, s. $141-147$.

62 Zob. C. Kosikowski, Publiczne prawo gospodarcze Polski i Unii Europejskiej, Warszawa 2010, s. 230-231.

63 Zob. C. Kosikowski, M. Etel, op. cit., s. 148-149.

64 Zob. ibidem, s. 138-140.

65 Ibidem, s. 150-181.

66 Zob. M. Etel, Kontrola i odpowiedzialność jako problemy charakteryzujace regulowana działalność gospodarcza (analiza z uwzględnieniem działalności telekomunikacyjnej), [w:] Instytucjonalny wymiar sektora telekomunikacyjnego. Sady i inne organy publiczne, red. J. Gola, W. Szydło, „Prace Naukowe Uniwersytetu Ekonomicznego we Wrocławiu” 495, 2017, s. 19 n. 
- nieuregulowana pozostaje kwestia kontroli działalności gospodarczej przedsiębiorcy ${ }^{67}$

— wiele przepisów ma charakter blankietowy 68 ;

Wypunktowane problemy należą do kluczowych, lecz mimo że są identyfikowane w nauce i judykaturze ${ }^{69}$, w u.PP zostały zupełnie pominięte ${ }^{70}$ albo rozwiązane tylko częściowo ${ }^{71}$ lub pozornie ${ }^{72}$. Braki te pozwalają dostrzec pewnego rodzaju fasadowość i powierzchowność reform. Owszem, wprowadzono zmiany, które korzystnie wpływają na jakość prawa i poszerzają zakres wolności gospodarczej, jednak jest ich zbyt mało i nie są wystarczająco konkretne, aby rzeczywiście poprawić sytuację prawną przedsiębiorcy.

Konkludując, należy uznać, iż trafny wydaje się wniosek, że na tle poprzednich ustaw określających zasady podejmowania, wykonywania i zakończenia działalności gospodarczej u.PP jest aktem nowoczesnym, który nie zażegnuje jednak fundamentalnych problemów trwale już wpisanych w prawo gospodarcze publiczne. W rezultacie stanowi zaledwie kolejny etap ewolucji, a radykalne reformy w dalszym ciągu pozostają niezbędne i konieczne.

\section{Bibliografia}

Biernat S., Podejmowanie i prowadzenie działalności gospodarczej - wolność gospodarcza de lege lata $i$ de lege ferenda, „Przegląd Prawa Handlowego” 1994, nr 9.

Biernat S., Wasilewski A., Ustawa o działalności gospodarczej. Komentarz, Kraków 1997.

CEIDG. Rzecznik Małych i Średnich Przedsiębiorców. Przedsiębiorcy zagraniczni w obrocie gospodarczym. Komentarz, red. G. Kozieł, Warszawa 2019.

Etel M., Kontrola i odpowiedzialność jako problemy charakteryzujace regulowana działalność gospodarcza (analiza z uwzględnieniem działalności telekomunikacyjnej), [w:] Instytucjonalny wymiar sektora telekomunikacyjnego. Sady i inne organy publiczne, red. J. Gola, W. Szydło, „Prace Naukowe Uniwersytetu Ekonomicznego we Wrocławiu” 495, 2017.

67 Zob. C. Kosikowski, Ustawa o swobodzie działalności gospodarczej. Komentarz, Warszawa 2013 , s. $497-548$.

68 Dotyczy to w szczególności treści konstytuujących obowiązków państwa wobec przedsiębiorców, a także zasad kontroli działalności gospodarczej; zob. Opinia Rady Legislacyjnej...

${ }^{69}$ O konieczności i zakresie zmian w u.SDG szerzej zob. C. Kosikowski, M. Etel, op. cit., s. 17 n.; M. Etel, Prawo działalności..., s. 28-36; idem, Kryzys prawa przedsiębiorców — potrzeba i zakres zmian w ustawie z 2.7.2004 r. o swobodzie działalności gospodarczej, [w:] Dysfunkcje publicznego prawa gospodarczego, red. E. Kruk, G. Lubeńczuk, M. Zdyb, Warszawa 2018, s. 51-64.

70 W ten sposób należy postrzegać art. 45-45 u.PP, które powielają przepisy u.SDG dotyczące kontroli działalności gospodarczej przedsiębiorcy wraz ze wszystkimi brakami i wątpliwościami.

${ }^{71} \mathrm{~W}$ ten sposób należy postrzegać nowe, skorygowane względem u.SDG, brzmienie definicji legalnej terminu „działalność gospodarcza” z art. 3 u.PP i terminu ,przedsiębiorca” z art. 4 u.PP.

${ }^{72} \mathrm{~W}$ ten sposób należy postrzegać zmiany w zakresie reglamentacji działalności gospodarczej wyrażone w art. 37-44 u.PP. 
Etel M., Kryzys prawa przedsiębiorców - potrzeba i zakres zmian w ustawie z 2.7.2004 r. o swobodzie działalności gospodarczej, [w:] Dysfunkcje publicznego prawa gospodarczego, red. E. Kruk, G. Lubeńczuk, M. Zdyb, Warszawa 2018.

Etel M., Nowy przedsiębiorca w ustawie z 6 marca 2018 r. — Prawo przedsiębiorców, „Acta Scientifica Academiae Ostroviensis" 2018, nr 2.

Etel M., Pojęcie przedsiębiorcy w prawie polskim i prawie Unii Europejskiej oraz w orzecznictwie sadowym, Warszawa 2012.

Etel M., Prawo działalności gospodarczej jako instrument rozwoju przedsiębiorczości, [w:] Prawne instrumenty oddziaływania na gospodarke, red. A. Powałowski, Warszawa 2016.

Korzeniewski M., Komentarz do art. 18, [w:] Prawo przedsiębiorców. Komentarz, red. A. Pietrzak, LEX 2019.

Kosikowski C., Nowe prawo działalności gospodarczej, „Przegląd Ustawodawstwa Gospodarczego" 1999, nr 2.

Kosikowski C., Publiczne prawo gospodarcze Polski i Unii Europejskiej, Warszawa 2010.

Kosikowski C., Ustawa o swobodzie działalności gospodarczej. Komentarz, Warszawa 2013.

Kosikowski C., Wolność gospodarcza w prawie polskim, Warszawa 1995.

Kosikowski C., Etel M., Nowe prawo działalności gospodarczej, Białystok 2014.

Kraszewski A., Preambuła, [w:] Prawo przedsiębiorców. Komentarz, red. A. Pietrzak, LEX 2019.

Lissoń P., Rzecznik Małych i Średnich Przedsiębiorców: ombudsman czy organ administracji rządowej, „Ruch Prawniczy, Ekonomiczny i Socjologiczny” 80, 2018, nr 4.

Niezgódka-Medek M., Szubiakowski M., Działalność gospodarcza. Spójność systemu prawnego, „Przegląd Prawa Handlowego" 1992, nr 2.

Państwo i prawo $w$ gospodarce rynkowej. Problemy dostosowawcze, red. C. Kosikowski, Łódź 1993.

Patyra S., Komentarz do art. 66-77, [w:] Prawo przedsiębiorców. Przepisy wprowadzajace do Konstytucji Biznesu. Komentarz, red. G. Kozieł, Warszawa 2019.

Piszcz A., Komentarz do art. 5, [w:] Prawo przedsiębiorców. Przepisy wprowadzające do Konstytucji Biznesu. Komentarz, red. G. Kozieł, Warszawa 2019.

Piszcz A., Objaśnienia prawne wedtug ustawy z 6.3.2018 r. - Prawo przedsiębiorców, „Monitor Prawniczy" 2018, nr 13, dodatek specjalny.

Sobczak K., Gospodarka rynkowa a władza publiczna, Warszawa 1998.

Taradejna R., Maj J., Ustawa o działalności gospodarczej (komentarz), Warszawa 1993.

Walaszek-Pyzioł A., Energia i prawo, Warszawa 2002.

Walaszek-Pyzioł A., Swoboda działalności gospodarczej, Kraków 1994.

Wasilewski A., Zasady prowadzenia działalności gospodarczej w Polsce, „Przegląd Ustawodawstwa Gospodarczego" 1988, nr 5-6.

Zdyb M., Komentarz do ustawy o działalności gospodarczej, Bydgoszcz 1997.

\title{
Law of Entrepreneurs: New quality and old problems
}

\author{
Summary
}

The Act of 6th March 2018 - Law of Entrepreneurs came in force on 30th April 2018. It continues the tradition of regulating the principles of undertaking, conducting, and terminating economic activity with the act on constitutional legitimacy, superior character, tasks and content. This 
article shows the essence of the reform as well as the construction and scope of the new regulations. Furthermore, it evaluates changes and directs the demands to the legislator.

Keywords: law of entrepreneurs, entrepreneurial activity, reform, new legal basis, traditional problems. 